\title{
Youth Crime in Karachi and London: A Comparative Analysis (Since 1990-2000)
}

\author{
Prof. Dr. Muhammad Ahmed Qadri, Ex. Vice Chancellor \\ Nazeer Hussain University Karachi, Pakistan \\ Muhammad Arshad, Research Scholar \\ Area Study Centre for Europe, University of Karachi, Pakistan
}

Doi:10.19044/esj.2020.v16n14p71～URL:http://dx.doi.org/10.19044/esj.2020.v16n14p71

\begin{abstract}
This paper focuses on performing a comparative analysis of youth crime in London (UK) and Karachi (Pakistan). The methodology adopted to carry out this research was of a descriptive study. The researcher on the basis of qualitative and quantitative findings has found the prevalence of juvenile delinquency in the different societies. It was found that even though the society of the UK possesses better mechanism and structure in the form of education, social lifestyle, police and law enforcing agencies, Britain is still faced with considerable challenges in minimizing juvenile delinquency within the Kingdom, specifically in London. The same has also been identified in the case of Pakistan where the situation and rate of juvenile delinquency are constantly increasing. This is due to various factors such as its economic condition, education standard, standard of living and others. It is, however, recommended that societies should make significant reforms in education, social, and other sectors in order to deal with the issue more effectively.
\end{abstract}

Keywords: Youth Crime, Juvenile Crime, London, Karachi

\section{Introduction}

It is evident that the young population is assumed to be the cornerstone of the society as it plays a vital role in lifting and directing the society in the right direction. Nevertheless, it is important to highlight that this important constituent of society is also been diverted towards different unwanted habits and practices. The factor of negligence and the sense of inferiority is been described as one of the most important and major driving force behind the attraction of this age group towards unwanted, unethical, and illegal practices in the form of crimes and others (Greer \& Reiner, 2015). It is notable that the increase in criminal practices or juvenile delinquency for the children of specified age has become a major concern for societies across the world, 
whether it is developed, developing or underdeveloped states. In this sense, it can be predicted that the prevalence of the concept of juvenile delinquency has been establishing its roots irrespective of the societies. However, the prevalence of these practices may vary from region to region (Young, Greer \& Church, 2017). This indicates that juvenile delinquency is a mix concept which is driven by both the individual, social, and other factors that aid in fostering this specific crime-related concept. According to the findings of Ehiemua (2014), juvenile delinquency is the crime practiced during the formative years. A more specific and compact definition of juvenile delinquency refers to the time period which is linked to the juveniles where the crimes took place. Here, it is important to highlight that law breaking and delinquency of juvenile is considered as one of the most important social issues across the world.

Since the crime committed by a juvenile is considered as one of the most important social dilemmas, significant developments at the public and governmental sector have also taken place. Therefore, with the emergence of non-profit organisations highlighting and mitigating the intensified effects, the role of social activities and other stakeholders of the society is crucial to effectively deal with this uncontrollable and growing epidemic of the society. This is done in order to control this growing epidemic to some extent (Klepser, 2014). It is therefore evident that young folks are considered to be the building block of every society. This is because they possess power and positive energy within themselves that has the capability of countering any challenge. Nevertheless, when this energetic and enthusiastic population starts moving forward in the wrong direction such as committing crimes or any other illegal or unethical practices, then this raises considerable challenges and ethical dilemma for the overall society. It was also stated by Brierley (2014) that the power and energy which the young population possesses is considered to be important and beneficial from different perspectives. Nevertheless, it is important to highlight that things become worst and undesirable when this important constituent of society starts taking interest in lawful activities. It is evident that young folks at the age of puberty are considered to be at the prime of their age where emotions, potentials, and other factors are found at its peak. However, the situation becomes worst once this population (juvenile) starts practices related to delinquency (Shands \& Grillo Mikrut, 2014). In this sense, this raises considerable challenges for different stakeholders in a manner that this issue has emerged as a concern and is one of the rapidly spread issue in majority of societies.

It is believed that the absence of the adequate mechanism for fostering empowerment among youth has played a pivotal role in elevating the rate of juvenile delinquency. The reason is that when the youth observes negligence and lack of support and guidance to either lead their career or lifestyle in the 
right direction, they eventually get attracted towards unlawful and unethical practices. In realization to the same concern, Kobek (2017) suggested that mechanism and the governmental policies in dealing with this kind of social dilemma plays an important role in either fostering or neglecting this kind of societal issues from the societies. This perspective highlights regions or countries that possess an adequate and proper mechanism to engage youth in meaningful and fruitful practices. Thus, it can be predicted that such particular society may possess a lesser ratio of juvenile delinquency. On the other hand, if a particular society does not possess adequate structure and mechanism to engage its youth in meaningful and beneficial practices, then this means that this specific society will be experiencing greater incidents and practices for juvenile delinquency.

Based on the same concern, the following study was conducted to ascertain an in-depth comparative analysis for two different cities or regions that are completely different from each other either in terms of social, cultural, mechanism or any other lifestyle structure and belief. The major focus and interest of the researcher is to comprehend the notion of juvenile delinquency taking a case study of Karachi in Pakistan. However, there are various reasons that justify the selection of this place in understanding juvenile delinquency. For instance, increasing criminal activities in Karachi, especially for the young population and the lack of research on this particular topic for the case of Pakistan, has forced the researcher to conduct the study in this region.

In realization of this, the following study has been conducted with the intention to examine whether the crime rate is higher in the two different cities, i.e., Karachi and London. Furthermore, there are two major purposes of conducting this study. One of the major reasons behind this study is to access the effect of political and administrative accountability specifically at the grass root level. The other more comprehensive aim behind conducting this research is to evaluate the different socio-cultural explanations and their likely impact on youth leading towards the adaption of the delinquent behavior for the case of Pakistan and London. Furthermore, the study aims to examine the social development of the youth crime in Karachi and London. This was done so that the concerned policies and strategies can also be compared contrastingly. The researcher has focused on descriptive studies where both the qualitative and quantitative aspects of the topic were included. On the one hand, the quantitative aspects was expressed using charts and figures, while the qualitative aspects, on the other hand, was included by means of the evidences collected from secondary sources. 


\section{Research Questions}

- What is Youth Crime or Juvenile Delinquency?

- What are the different factors that are associated with Youth Crime?

- What is the comparison between the Youth Crime in London and the Youth Crime in Karachi?

\section{Literature Review}

\section{Different School of Thoughts}

\section{Classical Institutions}

In the $18^{\text {th }}$ century, utilitarian philosophy-based institutions and schools were developed. Authors like Cesare Becerra and Jerry Bentham are the creators of the panopticon. Below are some arguments of many other classical college philosophers:

1. Individuals and communities have completely free willpower of living and how to act and behave.

2. The restriction is set upon the motivation of the individual as 'pleasure seeker'. They anticipate joy and happiness but avoid stress and troubles. Identifying with the constitutional thinking power determined and assessing the advantages and consumptions of each and every movement outcome.

3. Reasonable punishments can be helpful to minimize the crime ratio. Heavy and strict punishments may discourage and dissuade the offender from committing any crime. Punishments and penalties must be according to the law and legislation, i.e., according to the nature of the crime.

4. On-time and immediate punishment for the crime according to the law and legislation.

\section{Positivist School of Thoughts}

In the positive school, a logical framework is executed and rehearsed to learn and comprehend the human brain and its behavior. Positivist ideas further recognize three fundamental classifications which are:

- Comprise organic

- Mental

- Social positivism

\section{Italian School}

In the late $19^{\text {th }}$ century, the father of criminology, Cesare Lombroso, was working. He gave most of the ideas and concepts of science when it comes to the subject of criminology. He is also listed among the founding members of Italian university at Lombroso. He authorizes analysis and practical ways 
to deal with crimes and activities related to crimes (Mazzarello, 2011). Cesare has studied more on criminal anthropology and suggests that physiological, morphological, and natural characteristics can be used to catch criminals. Examples include the measurements and amounts of one's cheekbones or hairline estimations and observing the recessions and depressions to his ancestors.

\section{Sociological Positivist}

After the study of sociological positivist, it was shown that poverty is the major cause of committing antisocial acts. Also, the enrolment of subcultures, gathering, and division framework in social culture or low dimension of training and schooling foundations can prompt youngsters and children to carry out any criminal activity. Adolphe Quetelet, an incredible humanist, space expert, analyst and mathematician, examined the factual information and discovered a connection between sociological causes and crimes. He saw that sexual orientation, age, alcohol use, and schooling environments are the major cause of crime. Another well-known mathematician, Rawson W. Rawson, works with the crime information to prescribe and direct a connection between crime premiums and a number of people. He built up that stuffed populated field and urban areas are making a domain which is good for the crime. Joseph Fletcher and John Glyde additionally exemplified records to the Statistical Society of London on their abilities and help of crime (Shoemaker \& Ward, 2016). Henry Mayhew uses logical methodologies and an ethnographic methodology to direct the survey session of the social and methodical investigation of collective lead and poverty. Thus, this was expressed in his perspectives and experience in London (Groth, 2012). Emile Durkheim avoidable and inevitable demonstration of society emerged due to an uneven and unfair division of the effects and riches and various refinements among mutual, individual, or economic wellbeing.

\section{Combined Thoughts of Positivist and Classical}

When a crime is observed and detected, it violates the laws and norms of the society. Constitution and laws are made based on the laws and legislation upon the approval of the society. However, these laws are of two types:

- Natural laws which completely design upon the fundamental values of multiple cultures.

- Constitutional laws which set and design upon the legislation constitution that is derived from the cultural values. 


\section{Individual Factors Associated with Juvenile Crime}

Juvenile Crime is the involvement of young people in severe criminal activities and this is happening all over the world. In analyzing this, it is important to know what level of crime it is and what juvenile refers to. Crime is the activities which are not allowed or are not good for society and are against the norms and cultural values (Young, Greer \& Church, 2017). The most common types of crime we often hear about are kidnapping, rape, murder, robbery and many others.

\section{Biological and physical factors}

Biological characteristics can increase criminal behavior, and it can be transmitted easily to others. In addition, it plays a genetic role in the increase of crime ratio. The biological clarification can completely explain the misconduct of a couple of subjects. By and large, their job is restricted to either favoring or likely carrying out the crime (Reddy, 2018). The truth appears to demonstrate that these factors, without anyone else, do not influence the guiltiness of youngsters, especially in the event that they are not related with other social or surrounding factor. This is because crime is not the reality of a separated individual, yet of a social person.

\section{Psychological factors}

Numerous studies and research has been linked with the criminal behavior of youngsters. This is a progression of individual psychological factor that is acknowledged in these individuals in their early ages. Internal factors such as tension, stress or mental issues, for example, hyperactivity, issues or challenges of fixation and forceful or savage early conduct, shows a connection between these issues which results to a rough or reprobate behaviour (Sikand \& Reddy, 2017). These insufficiencies, issues of mental health, can impact the development of the personality of youngsters, making youthful, egocentric, indiscreet or forceful kids and youngsters. Hence, this can cause them serious and significant issues so as to accomplish the right socialization for the children and youngster.

\section{Family Factors}

In socialization, family plays a very vital role for every child. Belonging to a family is very important to the life of a child. Below are some factors that are important for children:

\section{The supervision and control of parents towards their children}

At the early stages of childhood, parental control and supervision plays a significant role in the children's personal development. As they guide their child about good and bad behaviour, they teach them how to live, how to talk, 
and more importantly how to be good with others and how to treat them (Gentile, 2014). This supervision and control also teaches us about the bad things which they must avoid doing by all means. If all parents give proper supervision and control towards their child development, they may never think of committing a crime.

\section{Presence of violence by parents towards their children}

Violence is not good in any situation. This is because it may lead to more complex and severe issues. In the case of children being violated by their parents, physical abuse of the child involves torturing the child (Hoskins, 2014). This affects the development of the children and they may be involved in drug use, violent activities as well as criminal activities.

\section{Families with criminal records}

In these cases, it is not easy for children to become normal as their family is affected due to the criminal record. There are also chances that the child can also be involved in any criminal activities. This is not always true that the child of a criminal would also be a criminal unless their parents are openly acting illegal crimes (Lageson, 2016).

\section{Lack of communication between parents and children}

The major drawback of current society is overburdened work, anxiety, and too much social gathering which causes the negligence of the relationship between children and parents. This is because parents are overburdening their children by involving them in too many extracurricular activities. Therefore, this causes a communication barrier between them, which makes them not to openly express their problems to them (Ante-Contreras, 2016).

\section{Financial shortages of the family}

Lack of finances makes the situation tough for fathers nowadays, which also causes lack of hygiene for their children. This, however, has resulted in some form of deficiencies. Families are attacked both mentally and physically, and it causes so much tension in the internal environment of the house. This is because if the families are facing tough financial situations, their houses are also overcrowded in terms of space. Therefore, these shortages of resources are the root cause of physical violence (Finkelhor, 2015). Also, their children are much more confident than that of the conflicted couple.

\section{Dissolved homes}

The separation of parents with young children has a significant negative impact on the lives of the children. Although the children of the independent parents are considered to be much more than that of the conflicted 
couples (Feigenbaum \& Muller, 2016), the separation of the couples leaves a lasting psychological impact on the young children in most cases. The psychological condition that arises as a result of separation of the parents often makes children more vulnerable to criminal activities.

\section{Social Factors}

The communities reflect our social structure and environment that is required to be studied with respect to various environmental situations (Canter \& Youngs, 2016).

The main social root causes of crime are as follows:

- Inequality

- No sharing of power

- Families are not supportive

- Inaccessibility to facilities or services

- Absence of leadership in communities

- The overexposure to television as resources of recreation

\section{Negative friendships}

Friendship plays a vital role in developing the character of an individual. A young individual surrounded by negative friendships is led into destruction. Peer pressure often forces young individuals to be in a circle of people that are involved in negative behaviour. Therefore, a forced negative trait will lead them towards addiction that will cause destruction to their kind (Rokven, 2017).

\section{Lack of employment}

Shortage of employment causes mental stress to young individuals. This is because the dependency on others causes a continuous frustration for the youth as no one is able to continuously support others. This lack of employment and the dissatisfaction from such life creates a frustrating environment for young people. Thus, this has become the main reason behind youth criminal activities (Ajimotokin, Haskins \& Wade, 2015). According to Karipova (2016), criminal activities are commonly found among unemployed people because these individuals can get involved in criminal activities to finance their living if they do not get a legal opportunity to earn money.

\section{The Media}

According to the researches, there is a conflict pointing out the negative impact of media on the young individual behavior. In most cases, the treatment given to the crimes by the media platform such as murders, aggravated robberies, etc. are mostly exaggerated. One of the serious 
consequences is the harm that has been caused to the minor communities. Such exaggeration of media gives society a deformed juvenile delinquency image (Greer \& Reiner, 2015). The violence factor has been seen on media in almost all programs presented. This is why it has become a commonplace since an early age with the damage that it entails.

\section{The Drugs}

The association of drugs addresses juvenile delinquency in two different ways. Firstly, emphasis is placed on the drugs issues and its usage by youth. Secondly, the drug addict's crime is evaluated and the transformation which is qualitatively suffered by juvenile delinquency in the world. According to Håkansson and Jesionowska (2018), people believe that drug abuse is the only reason which leads to disastrous consequences and is, however, not used moderately. More so, the world is getting affected by the issue of drugs.

\section{Classification of Crime}

Crime has been defined as the act which is conflicting to the legal code of a country. There are numerous different crime types which have been discussed further.

\begin{tabular}{|l|l|}
\hline \multicolumn{1}{|c|}{ Classification } & \multicolumn{1}{c|}{ Explanation } \\
\hline $\begin{array}{l}\text { Crimes against } \\
\text { Property }\end{array}$ & $\begin{array}{l}\text { The crimes against property include theft property without any } \\
\text { harm physically such as larceny, burglary, arson, and auto theft } \\
\text { (Nelson, 2015). Also, personal crimes have been committed } \\
\text { usually by young, poor, urban, and racial minorities as compared } \\
\text { to others. }\end{array}$ \\
\hline $\begin{array}{l}\text { Crimes against } \\
\text { Morality }\end{array}$ & $\begin{array}{l}\text { The crimes that have been done against morality are also known } \\
\text { as victimless crimes which have no victim. Its examples include } \\
\text { illegal gambling, drug use, and prostitution. }\end{array}$ \\
\hline Crimes against & $\begin{array}{l}\text { The crime that has been done against persons is also known as } \\
\text { personal crimes. It involves murder aggravated assault, theft, and } \\
\text { rape. A crime having no victim is a breach that does not have an } \\
\text { identifiable victim, which is the actual subject of crime. Such } \\
\text { offense is against our society because of its values, beliefs, and } \\
\text { behaviors. }\end{array}$ \\
\hline White-Collar Crime & $\begin{array}{l}\text { White-collar crimes are committed by individuals of high social } \\
\text { status according to their occupation. It involves stealing, tax } \\
\text { evasion, insider trading, and other income tax violations (Cliff \& } \\
\text { Desilets, 2014). It commonly produces less concern in the public } \\
\text { mind as compared to other crimes. Therefore, in terms of total } \\
\text { dollars, white-collar crimes are more important for society. }\end{array}$ \\
\hline Organized Crime & $\begin{array}{l}\text { Organized crime has multiple prospective and concepts because } \\
\text { its phenomenon varies. It involves the procedures of } \\
\text { organizational changes that have been done continuously. It also } \\
\text { shows dynamism and an extraordinary mutability. As a result of } \\
\text { this, few researchers of organized crime have proposals which are }\end{array}$ \\
\hline
\end{tabular}




\begin{tabular}{|l|l|}
\hline & $\begin{array}{l}\text { conflicting to the dictates of academic tradition. This position is } \\
\text { suitable from the constructivist viewpoint, but it also faces } \\
\text { numerous practical problems during fieldwork (Vorrath, 2015). } \\
\text { Organized crime is actually an activity of people who relate and } \\
\text { establish permanently to commit unlawful acts that also allows } \\
\text { them to obtain the advantages of economic power. }\end{array}$ \\
\hline
\end{tabular}

\section{Types of Crimes}

The following are the significant types of crimes that have been discussed in this study.

\begin{tabular}{|c|c|}
\hline Types & Description \\
\hline Rape / sexual assault & $\begin{array}{l}\text { Rape has been defined as the perpetrator's denial of the victim of } \\
\text { the crime. Its concepts and phenomena include an open and non- } \\
\text { exhaustive angle of many forms and ways in which coercion can } \\
\text { be practiced (Raj \& McDougal, 2014). The usage of force and } \\
\text { threat force by the perpetrator makes it impossible for the victim } \\
\text { to practice their right. }\end{array}$ \\
\hline Murder & $\begin{array}{l}\text { Murder is the death imposed on an individual illegally by another } \\
\text { person. However, deaths which occurred due to negligence or } \\
\text { suicide are excluded. According to the definition of some of the } \\
\text { old researches, murder is the death of a person caused by another } \\
\text { person for any reason. It includes three significant factors such as } \\
\text { the devastation of human life, cause and impact association among } \\
\text { death, and the act verified by the homicide and the intention to kill. }\end{array}$ \\
\hline Violence & $\begin{array}{l}\text { Violence is explained as the threat of physical usage along with } \\
\text { an intention to harm for multiple violent reasons. According to } \\
\text { the human rights point of view, it is evil (Truman, Langton \& } \\
\text { Planty, 2012). The negative effects of violence on the social and } \\
\text { economic development of a society are not limited. It also } \\
\text { occupies valuable resources that can be utilised in health and } \\
\text { education projects. }\end{array}$ \\
\hline Kidnapping & $\begin{array}{l}\text { Kidnapping is actually an activity which has been practically } \\
\text { always present since people joined together for hunting. It has } \\
\text { multiple purposes that damages the life of people in terms of } \\
\text { losing their close ones, losing money, and valuables. }\end{array}$ \\
\hline Perjury & $\begin{array}{l}\text { Perjury is the crime of false testimony that is explained as the } \\
\text { actions done by the witnesses and interpreters when making any } \\
\text { statement before a jurisdictional body. Also, this crime is } \\
\text { protected because of the attempt against the Public Authority } \\
\text { (Covey, 2015). It is all about lying under the oath of an } \\
\text { individual's own facts. }\end{array}$ \\
\hline Theft & $\begin{array}{l}\text { Theft is considered as one of the most common behavioral issues } \\
\text { reported by the communities. The true presence of theft generally } \\
\text { disfigures its recognition. Thus, the operational theft definition of } \\
\text { child-theft surveys reveals a big difference in sex. Parents report } \\
\text { theft as a significant issue in approximately } 10 \% \text { of all children } \\
\text { and } 2.5 \text { to } 5 \% \text { in all girls. }\end{array}$ \\
\hline Terrorism & $\begin{array}{l}\text { In the history of civilization, the identification of terrorism is } \\
\text { not new. Terrorism appeared in history during the French }\end{array}$ \\
\hline
\end{tabular}




\begin{tabular}{|l|l|}
\hline & $\begin{array}{l}\text { Revolution on the Committee of Public Health. Terrorism has } \\
\text { indicated many forms of behavior, or punishable conduct, that } \\
\text { is no longer reserved to the just proportion of the same. From } \\
\text { September 11, 2001, the significance of the term "terrorism" } \\
\text { got global dimensions like never before. This is because of the } \\
\text { possibility that any place broken by terrorist attacks rebounded } \\
\text { within all countries (Smith \& Zeigler, 2017). After the New } \\
\text { York attacks, the world was not the same, nor will it be again. } \\
\text { This is because it has added more phenomena to terrorism. }\end{array}$ \\
\hline Arson & $\begin{array}{l}\text { Arson was first defined as the destruction of a thing by fire. } \\
\text { However, this definition only focuses on fire as damage to } \\
\text { property that further incorporates the safety of other legal rights } \\
\text { such as the life and health of individuals through which we could } \\
\text { explain the crime of fire as the destruction of things (Grubb \& } \\
\text { Nobles, 2016). According to this, there is consent that properties } \\
\text { are not the only goods affected. Nonetheless, there is no such } \\
\text { clarity when identifying which legal right conquers the other. }\end{array}$ \\
\hline Bribery & $\begin{array}{l}\text { Bribery is defined as the act of promising, receiving, or giving to } \\
\text { receive money or some other valuable item with the aim of } \\
\text { corruption impacting public official duties. When a certain } \\
\text { amount of money has been offered in exchange for a corrupt act, } \\
\text { the official involved wants to accomplish that act for the offense } \\
\text { of bribery to be completed. }\end{array}$ \\
\hline $\begin{array}{l}\text { Cybercrime has been explained as the activity which utilises } \\
\text { computers as a criminal tool. It poses a danger both for networks } \\
\text { and for the information collected by it. In most of the countries } \\
\text { all around the world, there are no laws against this type of crime } \\
\text { (Broadhurst, 2014). Cybercrime includes illegal access to systems } \\
\text { of aliens, unlawful interception, interference or data loss, etc. }\end{array}$ \\
\hline Cybercrime
\end{tabular}

\section{Findings}

\section{Evolution of youth crime in the UK and London}

Specifically, in the UK, the notion of juvenile delinquency includes all minors within the age of 21 years. However, there are still some limitations and peculiarities with this division. There is a sub division between the age of ten and seventeen years. This subdivision is also responsible for setting the level and intensity of the crime and its punishment (O'Connor, 2015). As per the English law, the offender is assumed as a minor child. However, for the child between fourteen to seventeen years, the law refers to the offender as an adolescent. It is important to highlight that different Community Homes have also been developed for different minor age groups, and the UK law is also willing to expand the range of juvenile delinquency to 22 years (Young, 2017). This particular division will not be treated as adults. However, in some serious cases, they will have to be sent to the sentence located at Borstals. 


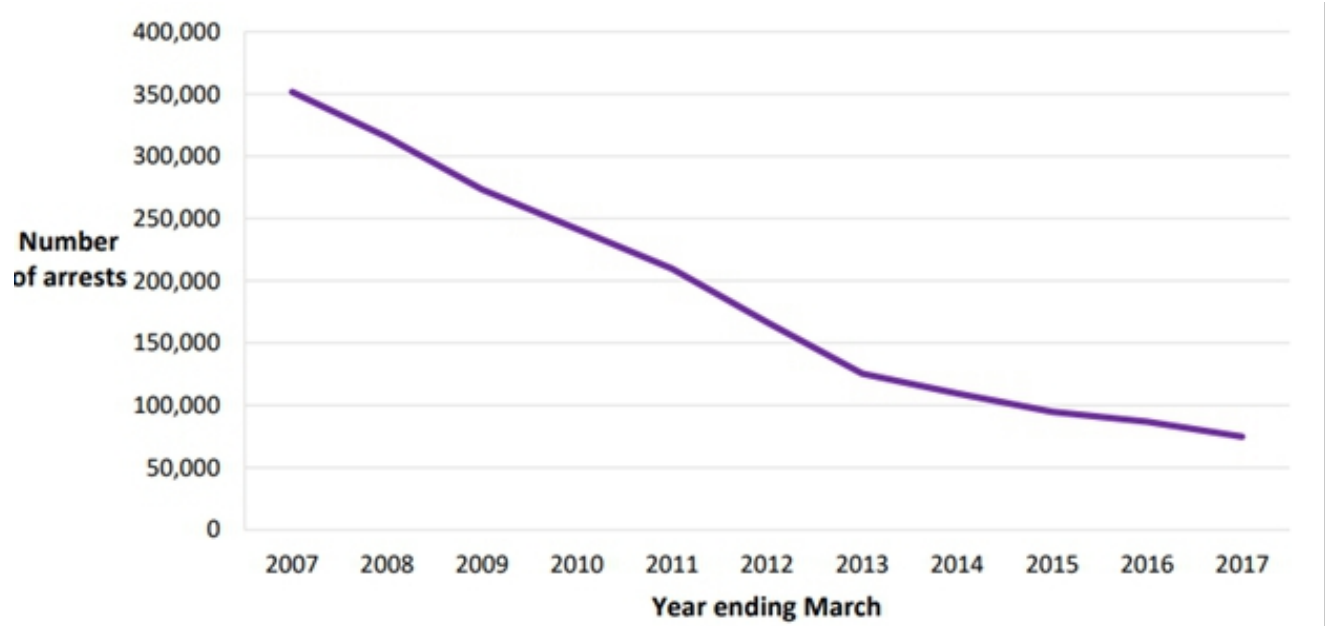

Figure 1. Arrests of Children and Young People for Notifiable Offences, England (Young, 2017)

As per the statistics, within the UK each year, there have been reports of at least $50 \%$ of the total offenses that are found in the procedural offenses which lies within the ages of 10-21. In the case of boys, it is found that there is a significant increase in criminal activities especially within the age range of 10-14. However, it is important to highlight that these number reduces after the age of 14. This indicates that from the age of 5-20, half of the population which commits crime belongs to the age of 14 (Crawford, 2013). Here, it is important to highlight that the female ratio in relation to boys has also increased drastically. It is believed that due to the transformed structure of the society, the ratio of female delinquency has also increased drastically by $10 \%$ in comparison to boys. As per the recent study of Cambridge University, it has been identified in the report that among children and young people, the antisocial behavior has experienced significant growth. Different reasons have been observed that have resulted in this elevated anti-social behavior among the young population of London. The constantly declining mutual respect, fostering anti-social behavior, and materialism are some of the major reasons that are responsible for this evolution of youth crime in the UK and specifically in London. 
Last year prevalence of offending, by age and sex

\begin{tabular}{lccc}
\hline & $\begin{array}{c}\text { Males } \\
\%\end{array}$ & $\begin{array}{c}\text { Females } \\
\%\end{array}$ & $\begin{array}{c}\text { Ratio* } \\
\%\end{array}$ \\
\hline $12-13$ years & 15 & 12 & 1.3 \\
$14-15$ years & 33 & 18 & 1.9 \\
$16-17$ years & 26 & 16 & 1.6 \\
$18-21$ years & 35 & 15 & 2.4 \\
$22-25$ years & 28 & 8 & 3.5 \\
$26-30$ years & 19 & 7 & 2.8 \\
\hline Note: \\
The ratio is based on the percentages before rounding.
\end{tabular}

Table 2. Prevalence of offending (Bureau of Justice Statistics)

It is notable that juvenile crime has become a debating concern among media, political, and social sector. Different stakeholders provide different viewpoints in relation to the causes and factors that have resulted in increased juvenile delinquency. The increased rate of juvenile delinquency within London is being associated with the declining mortality and the erosion of the family. Furthermore, the role of the media and entertainment industry has also been irresponsible. This has led to negativity and unlawful activities by misrepresenting heroic actions (Mazzarello, 2011). Different high-profile cases of juvenile delinquency have also been reported such as the murder of James Bulger in 1993. Also, many other cases justifies the evolution of youth crime in London, UK.

\section{Youth Crime in Karachi (Pakistan) and Comparison with London (UK)}

It is evident that criminal activities within the country exist in different forms. Specifically, crimes in the form of murders, target killing, kidnapping, extortion, harassment, fraud, drugs trafficking, human trafficking and most importantly terrorism has deep roots in the society (Ahmed, 2016). More so, Pakistan is a less developed, less literate, and less structured country. As a result of this, the country and different stakeholders of the society have failed to provide adequate opportunities and direction to engage its youth in healthy and good practices. Consequently, it is observed that societies in Pakistan specifically Karachi has also been facing considerable challenges from this growing epidemic of juvenile delinquency. Since Pakistan has been facing considerable financial crisis, this have eventually resulted to negligence and lack of financial assistance and programs offered to youth. Unlike London, the youth in Karachi and all over Pakistan is facing challenges in the availability of quality education and the adequate jobs that can enable them to live proudly 
in the society. Apart from this, most youths in Karachi also believe in the use of force to get what they want as evidenced from different studies. This is also one factor that leads to the increased juvenile delinquency rate in the city.

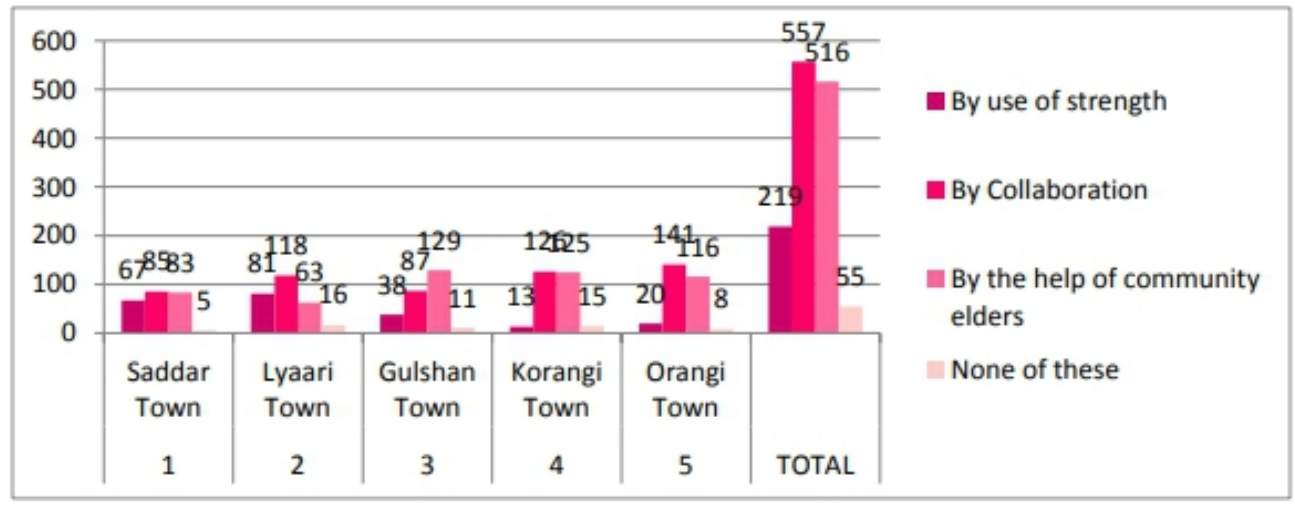

Figure 3. Youth perception on conflict resolution (Search for Common Ground, 2014)

Since Pakistan possesses dual standards in different domains such as in education, employment or even legislation, the rate of juvenile delinquency has also been increasing drastically. Due to family structure and social and religious factors, juvenile delinquency is also been resisted (Kalia, 2016). Nevertheless, the other factors that comprise of educational factors and the presence of violence in the society are much improved and satisfactory in the case of London (Crawford, 2013). Besides social education and lack of controlling and monitoring of the youth, it is also important to highlight that prevalence of disappointment where the young population sees the old ones struggle for the basic necessity and rights show that the state has failed. This leads to juvenile delinquency as a result of improper structure and mechanism. Therefore, this social epidemic is constantly growing.

\section{Conclusion and Recommendations}

In conclusion, this descriptive study using secondary qualitative and quantitative evidences shows a sound comparative analysis. Here, the researcher found that the social epidemic of juvenile delinquency exists in both societies. Even though London possesses a better social and educational standard in comparison with Karachi, there is still a considerable rate of juvenile delinquency. Nevertheless, it was also found that Karachi has already been facing considerable challenges such as declining social standard. Also, some of the social factors in Karachi like close monitoring of the youth and the strong family structure resists juvenile delinquency to a great extent. Other countless intensifying challenges in the form of the financial crisis, education and lifestyle standard, and social and economic injustice have not only resulted 
in the development and prevalence of the juvenile delinquency but, at the same time, escalated juvenile delinquency.

Based on the findings of this study, below are some recommendations to counter the issue of juvenile delinquency in both countries.

- Follow the prevention strategy rather than repression as this may aid in the prevention of juvenile delinquency. To achieve this, significant reforms need to be implemented in sectors like education, finance and economics, employment, etc.

- The social activist, working bodies, and the media are required to play a positive and responsible role to identify the criminal offense and similar activities. Also, all these stakeholders should provide possible solutions and adequate strategies to better prevent this growing epidemic in the society.

- There is the need to also modify and alter the role of law in enforcing agencies, especially within Pakistan. Since the less educated and irresponsible institutions of Pakistan follow the conventional practices of treating criminals, there is no concept of rehabilitation in Pakistan. Therefore, from these perspectives, there is a need to make significant reforms to better tackle juvenile delinquents.

\section{References:}

1. Ahmed, Z. S. \& Khan, Z. (2016). Direct and indirect impacts of terrorism on youth in Pakistan. Journal of the Research Society of Pakistan, 53(1).

2. Ajimotokin, S., Haskins, A. \& Wade, Z. (2015). The Effects of Unemployment on Crime Rates in the US.

3. Ante-Contreras, D. (2016). Distracted parenting: How social media affects parent-child attachment.

4. Brierley, J. \& Larcher, V. (2014). Clinical trials of contraceptive agents in those under 16 years of age: Are they necessary, ethical or legal?. Archives of disease in childhood, 99(12), 1070-1073.

5. Broadhurst, R., Grabosky, P., Alazab, M., Bouhours, B. \& Chon, S. (2014). An analysis of the nature of groups engaged in cyber crime. An Analysis of the Nature of Groups engaged in Cyber Crime, International Journal of Cyber Criminology, 8(1), 1-20.

6. Canter, D. \& Youngs, D. (2016). Crime and society.

7. Cliff, G. \&Desilets, C. (2014). White collar crime: what it is and where it's going. Notre Dame JL Ethics \& Pub. Pol'y, 28, 481.

8. Covey, R. D. (2015). Recantations and the perjury sword. Alb. L. Rev., 79, 861.

9. Crawford, A. \& Newburn, T. (2013). Youth offending and restorative justice. Willan. 
10. Dalberis, R. (2015). Extreme Levels of Poverty and Inequality May Lead to Equally High Levels of Social Conflict and Crime.

11. Ehiemua, S. (2014). Juvenile delinquency: A comparative study between child rearing practices in developed and developing countries. European Journal of Research in Social Sciences Vol, 2(4).

12. Feigenbaum, J. J. \& Muller, C. (2016). Lead exposure and violent crime in the early twentieth century. Explorations in economic history, 62, 51-86.

13. Finkelhor, D., Turner, H., Shattuck, A., Hamby, S. \& Kracke, K. (2015). Children's exposure to violence, crime, and abuse: An update. Washington, DC: US Department of Justice, Office of Justice Programs, Office of Juvenile Justice and Delinquency Prevention.

14. Gentile, D. A., Reimer, R. A., Nathanson, A. I., Walsh, D. A. \& Eisenmann, J. C. (2014). Protective effects of parental monitoring of children's media use: A prospective study. JAMA pediatrics, 168(5), 479-484.

15. Greer, C. \& Reiner, R. (2015). Mediated Mayhem: Media, crime and criminal justice

16. Greer, C. \& Reiner, R. (2015). Mediated Mayhem: Media, crime and criminal justice.

17. Groth, H. (2012). The Soundscapes of Henry Mayhew Urban Ethnography and Technologies of Transcription. Cultural Studies Review, 18(3), 109-30.

18. Grubb, J. A. \& Nobles, M. R. (2016). A spatiotemporal analysis of arson. Journal of research in crime and delinquency, 53(1), 66-92.

19. Hoskins, D. (2014). Consequences of parenting on adolescent outcomes. Societies, 4(3), 506-531.

20. Kalia, S. (2016). Criminal networks and governance: a study of Lyari Karachi. The South Asianist, 4(2).

21. Karipova, A., Voznyak, O., Babajanyan, Y., Serikbayev, A. \& Kozhantayeva, Z. (2016). About the Influence of Population Growth, Unemployment on the Crime Situation in the Cities of Astana and Almaty. International Journal of Environmental and Science Education, 11(11), 4790-4800.

22. Klepser, M. E. (2014). Socioeconomic impact of seasonal (epidemic) influenza and the role of over-the-counter medicines. Drugs, 74(13), 1467-1479.

23. Kobek, L. P. (2017). The State of Cybersecurity in Mexico: An Overview. Mexico Institute. https://www. wilsoncenter. org/sites/default/files/cybersecurity_in_mexico_an_overview.pdf. 
24. Lageson, S. E. (2016). Found out and opting out: The consequences of online criminal records for families. The ANNALS of the American Academy of Political and Social Science, 665(1), 127-141.

25. Mazzarello, P. (2011). Cesare Lombroso: an anthropologist between evolution and degeneration. Functional neurology, 26(2), 97.

26. Nelson, P. (2015). Violent and property crime trends: local and international comparisons. Crime and Justice Statistics Bureau Brief.

27. Noor, F. \& Lodhi, F. A. (2014). Causes of Crimes in Educated Youth of Sindh: A Survey Study. Asian Journal of Social Sciences \& Humanities Vol, 3, 2.

28. O’Connor, R. \& Waddell, S. T. E. P. H. A. N. I. E. (2015). What works to prevent gang involvement, youth violence and crime. A Rapid Review of Interventions Delivered in the UK and Abroad, Early Intervention Foundation, London.

29. Raj, A. \& McDougal, L. (2014). Sexual violence and rape in India. The Lancet, 383(9920), 865.

30. Reddy, K. J., Menon, K. R. \& Hunjan, U. G. (2018). Neurobiological Aspects of Violent and Criminal Behaviour: Deficits in Frontal Lobe Function and Neurotransmitters 1. International Journal of Criminal Justice Sciences, 13(1), 44.

31. Rokven, J. J., de Boer, G., Tolsma, J. \& Ruiter, S. (2017). How friends' involvement in crime affects the risk of offending and victimization. European journal of criminology, 14(6), 697-719.

32. Search for Common Ground (2014). Youth Violence in Karachi. Available at https://www.sfcg.org/wpcontent/uploads/2015/07/KYI_Baseline_Report_Final.pdf

33. Shands, K. \& Grillo Mikrut, G. (2014). Living Language, Living Memory: Essays on the Works of Toni Morrison. Södertörnshögskola.

34. Shoemaker, R. \& Ward, R. (2016). Understanding the criminal: Record-keeping, statistics and the early history of criminology in England. British Journal of Criminology, 57(6), 1442-1461.

35. Sikand, M. \& Reddy, K. J. (2017). Role of Psychosocial Factors in Criminal Behaviour in Adults in India. International Journal of Criminal Justice Sciences, 12(1).

36. Smith, M. \& Zeigler, S. M. (2017). Terrorism before and after 9/11-a more dangerous world?.Research \& Politics, 4(4), 2053168017739757.

37. Truman, J. L., Langton, L. \& Planty, M. (2012). Criminal victimization, 2012.

38. Vorrath, J. (2015). Organized crime and development: challenges and policy options in West Africa's fragile states. 
39. Young, S., Greer, B. \& Church, R. (2017). Juvenile delinquency, welfare, justice and therapeutic interventions: a global perspective. BJPsych bulletin, 41(1), 21-29..

40. Young, S., Greer, B. \& Church, R. (2017). Juvenile delinquency, welfare, justice and therapeutic interventions: a global perspective. BJPsych bulletin, 41(1), 21-29.

41. Young, S., Greer, B. \& Church, R. (2017). Juvenile delinquency, welfare, justice and therapeutic interventions: a global perspective. BJPsych bulletin, 41(1), 21-29.

42. Yusuf, H. (2012). Conflict dynamics in Karachi (Vol. 19). Washington: US Institute of Peace. (2013). Informality and political violence in Karachi. Urban Studies, 50(15), pp.3099-3115. 